\title{
Mineralogy of the Jagersfontein kimberlite - an unusual Group I micaceous kimberlite - and a comment on the robustness of the mineralogical definition of 'orangeite'
}

\author{
Taylor, W.R. ${ }^{1}$, and Kingdom, L. ${ }^{2}$ \\ ${ }^{1}$ R.S.E.S., Australian National University, Canberra, A.C.T. 0200, Australia \\ ${ }^{2}$ Geology Department, Australian National University, Canberra, A.C.T. 0200, Australia
}

Group II kimberlites were defined by Smith (1983) and Smith et al. (1985a) as a variety of micaceous kimberlite with distinctive geochemical and isotopic characteristics. Group II kimberlites have not been unequivocally recognized outside southern Africa. Such rocks are believed to be derived from (or at least include a component of) an ancient lithospheric mantle source in contrast to the 'asthenospheric' source characteristics of Group I serpentine-calcite kimberlites. Mitchell (1995) has recently proposed that Group II kimberlites represent a separate magma type and that they are sufficiently distinctive, petrographically and mineralogically, to warrant the new rock name 'orangeite'.

Mitchell (1995) identifies a number of mineralogical criteria which characterize orangeites, these include the presence of: (i) abundant phlogopite as macrocrysts, phenocrysts and groundmass grains showing compositional zonation from phlogopite to tetraferriphlogopite; (ii) rounded olivine macrocrysts and magnesian (typically Fo 91-93) euhedral primary olivine phenocrysts; (iii) primary groundmass diopside; (iv) spinel of magnesiochromite to titanomagnetite composition; (v) Sr- and REE-rich perovskite; (vi) Sr-rich apatite; (vii) various titanate minerals and Mn-rich ilmenite. Phases absent from orangeites, compared to Group I kimberlites, are monticellite, magnesian ulvospinel and Ba-rich phlogopite.

Although Group II kimberlites appear to be confined to southern Africa, there are a number of examples of diamondiferous micaceous kimberlite from other cratonic regions, e.g. the Aries kimberlite of northwest Australia (Edwards et al., 1992), which appear to have at least some mineralogical characteristics in common with orangeites. In southern Africa a few micaceous kimberlites with Group I isotopic signatures have been recognized, e.g. the Jagersfontein kimberlite (Smith et al., 1985a). Such kimberlites would be described as 'non-archetypal' in the terminology of Mitchell (1995). Because the detailed mineralogy of these kimberlites are poorly known, we have examined in some detail a petrographically fresh example of Jagersfontein kimberlite (J1) sampled from old mine workings. An important aim of this investigation was to establish the robustness of Mitchell's mineralogical criteria for identification of orangeites, i.e. mineralogically, how easily can non-archetypal, micaceous Group I kimberlites be confused with orangeites?

The Jagersfontein kimberlite pipe is located on the southern margin of the Kaapvaal craton and has been dated at $86 \mathrm{Ma}$ (Smith et al., 1985b). It is a well known locality for peridotitic and eclogitic mantle xenoliths. Some of these appear to have been sampled from the deeper upper mantle and transition zone (Sautter et al., 1991) suggesting the kimberlite magma originated at depths $>300 \mathrm{~km}$. As with other Group I kimberlites, Jagersfontein hosts a variety of megacryst minerals including a Cr-poor megacryst suite, although ilmenite is uncharacteristically absent (Hops et al, 1992). Jagersfontein is also a well known locality for exotic titanate minerals which occur in mineral concentrates; they are probably derived from disaggregated metasomatic peridotites (Haggerty, 1983). Although much is known about the xenoliths and xenocrysts from the Jagersfontein kimberlite, little detailed information is available on the nature of the host kimberlite itself.

Kimberlite sample $\mathrm{J} 1$ contains abundant rounded olivine macrocrysts (up to $\sim 1 \mathrm{~cm}$ size). Some of the macrocrysts contain inclusions of $\mathrm{Cr}$-spinel or $\mathrm{Cr}$-diopside attesting to their xenolithic origin, presumably as disaggregated mantle wall-rock peridotites. Rounded phlogopite macrocrysts are relatively common. Carbonate-phlogopite-serpentine and glimmerite xenoliths, up to $\sim 1 \mathrm{~cm}$ sice and of uncertain origin, are also present. Phenocrysts and microphenocrysts comprise largely subhedral olivine, now mostly converted to 
serpentine, and lesser phlogopite. These are set in a groundmass composed dominantly of mica, with less abundant perovskite, opaque oxides, diopside, apatite, serpentine and calcite. On face value this petrographic description appears much closer to orangeite than to Group I kimberlite. Details of phase chemistry also reveals similarities with orangeite. SEM studies indicate that groundmass mica laths are zoned with phlogopite cores and relatively thin tetraferriphlogopite-rich rims. The phlogopite compositional trends, shown in Figure 1, are essentially identical to those found in orangeite; $\mathrm{BaO}$ and $\mathrm{TiO}_{2}$ contents are low. Groundmass diopside (mg\# 89-96, $\mathrm{TiO}_{2}$ 0.3-0.8 wt\%, $\mathrm{Al}_{2} \mathrm{O}_{3}<0.3 \mathrm{wt} \%, \mathrm{Na}_{2} \mathrm{O}<0.6 \mathrm{wt} \%$ ) is relatively common as small prismatic grains ( $\leq 60$ microns in size) which may occur as inclusions in phlogopite. Compositionally, the diopside seems to be identical with iron-poor clinopyroxene from orangeite and with some clinopyroxenes from kimberlite (Mitchell, 1995). There is no evidence that the diopside has formed as a result of contamination of the magma with siliceous material.

Fig.1 Jagersfontein Phlogopite Compositions
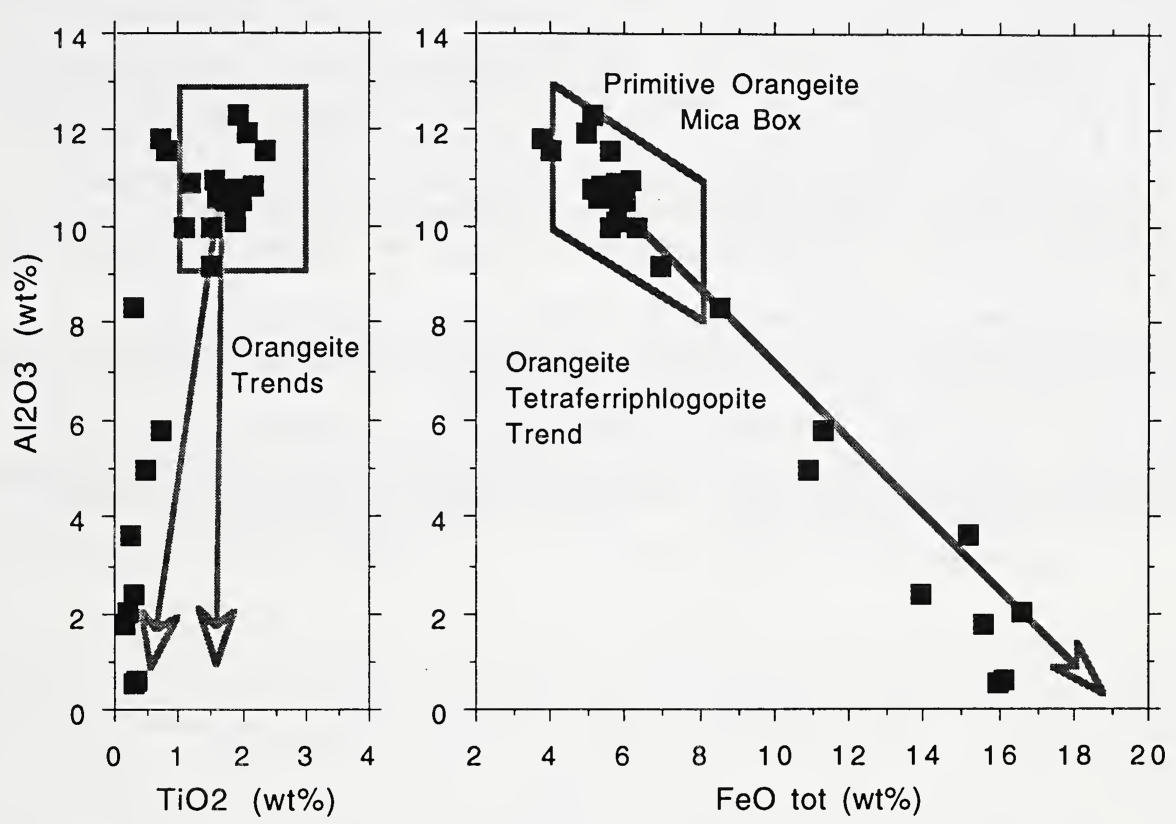

Among the accessory phases, the Jagersfontein kimberlite contains high-Sr fluorapatite (2.5$5.5 \mathrm{wt} \% \mathrm{SrO}$ ) very similar to those occurring in orangeite and distinct from the Sr-poor apatite (SrO <1 wt\%) believed to be characteritic of kimberlite (Mitchell, 1995). Perovskite, however, is relatively poor in $\mathrm{SrO}(\sim 0.3 \mathrm{wt} \%)$ and in $\mathrm{Ce}_{2} \mathrm{O}_{3}(1.0-2.5 \mathrm{wt} \%)$ but richer in $\mathrm{Nb}_{2} \mathrm{O}_{5}(0.8-1.2 \mathrm{wt} \%)$ compared to that occurring in most orangeites. The groundmass opaque oxide phases consist of magnetite-rich titanian magnesian chromite (cr\# 86) and titanomagnetite $\left(\sim 7 \mathrm{wt} \% \mathrm{TiO}_{2}\right)$ which are identical to the spinel compositions considered characteristic of orangeites. No unusual titanate phases or Mn-rich ilmenite were encountered. In terms of olivine compositions, macrocrysts range from Fo 90-94 and phenocrysts and microphenocrysts are generally more iron-rich with a Fo 86-92 range. These ranges are most similar to those found in Group I kimberlites (Mitchell, 1995).

In summary, the Jagersfontein micaceous kimberlite has petrographic and mineralogical features in common with both orangeites and archetypal kimberlites yet it isotopically belongs with Group I kimberlites. In terms of mineral chemistry alone it would probably be classified (incorrectly) by most petrologists as an orangeite, albeit an atypical one. It is our view that the mineralogical criteria used to establish orangeite as a separate rock species may not be sufficiently robust to allow discrimination of orangeite from other varieties of micaceous 
kimberlite. This is a particularly important consideration when dealing with kimberlites from parts of the world other than southern Africa because, on other cratons, micaceous kimberlites of Group I affinity seem to be relatively common whereas orangeites are rare or nonexistent. Convergence of mineralogical composition, which essentially reflects major and minor element abundances in the rock and its crystallization history, is to be expected for broadly compositionally similar (but not necessarily genetically similar) magmas emplaced in similar, high-level environments. To establish clear differences in magma type more reliance may need to be placed on appropriate trace-element and isotopic geochemical discriminators, although the exact genetic significance of such differences is not fully understood at this time.

\section{References}

Edwards, D., Rock, N.M.S., Taylor, W.R., Griffin, B.J., and Ramsay, R.R., 1992, Mineralogy and petrology of the Aries diamondiferous kimberlite pipe, central Kimberley block, Western Australia, J. Petrol., 3, p.1157-1191.

Haggerty, S.E., 1983, The mineral chemistry of new titanates from the Jagersfontein kimberlite, South Africa: implications for metasomatism in the upper mantle. Geochim. Cosmochim. Acta, 47, p.1833-1854.

Hops, J.J., Gurney, J.J., and Harte, B., 1992, The Jagersfontein Cr-poor megacryst suite toward a model for megacryst petrogenesis, J. Volcanol. Geotherm. Res., 50, p.143-160.

Mitchell, R.H., 1995, Kimberlites, orangeites and related rocks. 410 p. Plenum Press.

Sautter, V., Haggerty, S.E., and Field, S., 1991, Ultra-deep (>300 km) ultramafoc xenoliths: new petrologic evidence from the transition zone, Science, 252, p.827-830.

Smith, C.B., 1983, Pb, Sr, and $\mathrm{Nd}$ isotopic evidence for sources of African Cretaceous kimberlites, Nature, 304, p.51-54.

Smith, C.B., Gurney, J.J., Skinner, E.M.W., Clement, C.R., Ebrahim, N., 1985a,

Geochemical character of southern African kimberlites: a new approach based on isotope constraints, Trans. Geol. Soc. Sth Africa, 88, p.267-280.

Smith, C.B., Allsopp, H.L., Kramers, J.D., Hutchinson, G., and Roddick, J.C., 1985b, Emplacement ages of Jurassic-Cretaceous South African kimberlites by the Rb-Sr method on phlogopite and whole rock samples, Trans. Geol. Soc. Sth Africa, 88, p.249-266. 